\title{
A Review of the Phytochemistry and Biological Activities of Hibiscus sabdariffa (Zobo) Plant
}

Kasimu Ghandi Ibrahim ${ }^{1,2}$ and Nasiru Sani Kangiwa

${ }^{1}$ Department of Physiology, Faculty of Basic Medical Sciences,

College of Health Sciences, Usmanu Danfodiyo University,

P.M.B. 2254, Sokoto, Nigeria

${ }^{2}$ Centre for Advanced Medical Research and Training Usmanu Danfodiyo University, P.M.B. 2254, Sokoto, Nigeria

Corresponding author:

Kasimu Ghandi Ibrahim

Department of Physiology, Faculty of Basic Medical

Sciences, College of Health Sciences, Usmanu Danfodivo

University, P.M.B. 2254, Sokoto, Nigeria

email: ghandi.kasimu@udusok.edu.ng

Tel: +2348035046118

\begin{abstract}
Hibiscus sabdariffa (HS) is a plant from the Malvaceae family that is grown widely in most of Asia and tropical Africa. The various parts of the plant are used traditionally as food in form of beverages or salads and as medicine. In folklore, HS has been used to treat many ailments including cardiac and nerve ailments, induction of diuresis and lactation among others. Scientific studies have also demonstrated the antihypertensive, antidiabetic, anti-obesity and anti-hyperlipidaemic properties of $H S$. These biological activities are thought to be as a result of the battery of phytochemicals in $H S$ that have strong antioxidant activity and that inhibit $\alpha$-amylase, $\alpha$-glucosidase, angiotensin converting enzyme, calcium channel blockage and direct vasorelaxant effects. Some of the phytochemicals that are thought to be responsible for these biological effects include anthocyanins, flavonoids and organic acids.
\end{abstract}

There is however the need for more robust researches including controlled clinical trials to validate these biological activities with a view to bringing the benefits closer to the bedside.

Keywords: Hibiscus sabdariffa, Malvaceae, anthocyanins, flavonoids

\section{Introduction:}

Hibiscus sabdariffa (HS) is an annual shrub which belongs to the Malvaceae family (1). It is called Roselle in English speaking countries while in North Africa, it is called karkade or carcade (2). It can be grown as a mono crop or mixed with other crops (3). It is thought to be native to Asia or tropical Africa where it is grown as a garden crop. In Sudan HS is a major export crop (4).

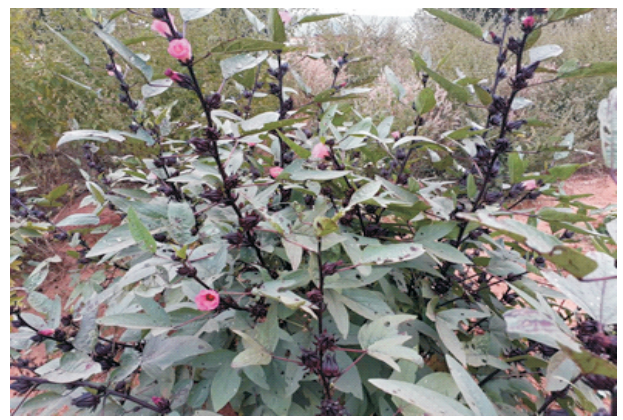

Figure 1: Hibiscus sabdariffa plant in Sokoto, North West Nigeria

\section{Botanical description}

$\boldsymbol{H S}$ belongs to the kingdom Plantae, division Angiosperms, class Eudicots, order Malvales, family
Malvaceae, genus Hibiscus and species sabdariffa (5). It can grow to 2.4 meters or more in height (6) and has a deep penetrating tap root. It has smooth cylindrical, typically dark green to red stems (1). The leaves are alternate, $7.5-12.5 \mathrm{~cm}$ long, green with reddish veins and long petioles. The flowers are hermaphrodite and are insect pollinated (7). It has a red calyx that consists of 5 large sepals with an epicalyx and bracteoles around the base (3). The capsule turns brown and splits open when it is matured and dry. Each capsule contains 22-34 kidneyshaped seeds which are 3-5 mm long, light-to-deep brown in colour and covered with minute stout hairs (8). The extracts of the calyx, stems and leaves are acidic (3).

\section{Traditional and economic uses of $H S$}

The different parts of the plant have many traditional uses in different communities across the world.

\section{Uses of $H S$ calyces}

Among the different parts of the plant, the calyces are the most extensively used for both traditional and medicinal purposes. Fresh and dried HS calyces are used in the 
preparation of hot or cold beverages (9), wine, jam, confectionaries, ice cream, chocolates, flavouring agents, puddings and cakes $(3,10)$. The calyces are boiled and processed into a local soft drink known as "Zobo" in Nigeria (11) or "agua de Jamaica” in Mexico. (6)

$H S$ calyces are used to treat cardiac and nerve ailments and to induce diuresis (12). An infusion of the calyces extracts has also been used to lower body temperature (13) and to treat drunkenness (2). Extracts of the calyces are used in North Africa as a remedy for sore throats and cough as well as genital problems (3). The calyces also provide a good source of food colourant due to the presence of anthocyanins, which are naturally colourful. In Pakistan, the calyces serve as a source of pectin for fruit-preservation industry while in India they are used as vegetables (8).

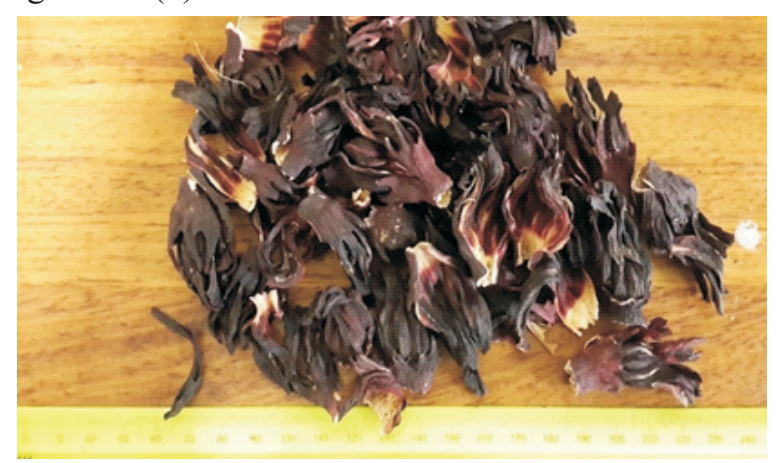

Figure 2: Dried calyces of Hibiscus sabdariffa

\section{Hibiscus sabdariffa leaves}

The leaves of HS are consumed raw or cooked as a sourflavoured vegetable or condiment (14). In Sudan and Malaysia, they are eaten green or dried cooked with onions and ground nuts (14). In India, the tender leaves and stems are eaten as salad and for making chutney during rainy season and dry them for during off-season use (8).

\section{Hibiscus sabdariffa seeds}

The seeds of HS are eaten roasted or ground into meals (15). As powder, they are used in meals such as oily soups and sauces or as a substitute for coffee (16). Hibiscus sabdariffa seeds are also used in the treatment of indigestion and dysuria (2) and for inducing or enhancing lactation (17). The Chinese use the seeds for oil extraction. The yield of the extracted oil from red and white HS seeds was found to be $21.1 \%$ (18). HS seeds are rich in protein and after oil extraction, they are boiled and eaten in soups and are also used as a substitute for coffee in Africa (8). The seeds are fermented to produce a meat substitute condiment (8).

\section{Phytochemistry of $H S$ calyces}

HS phytochemistry has been extensively studied and documented. Table 1 shows the phytochemical composition of different parts of $H S$.

Table 1: Phytochemical composition of Hibiscus sabdariffa

\section{Part of the plant Chemical constituents}

Flower Carbohydrates, arabinans, mannose, sucrose, thiamin, xylose, mucilage, niacin, pectin, proteins, fat, a $r$ a b i n o a 1 a c t a $n s$, rhamnogalacturans, riboflavin, $\beta$ carotene, phytosterols, citric acid, ascorbic acid, fruit acids, maleic acid, malic acid, hibiscic acid, oxalic acid, tartaric acid, (+)-allooxycitronic acid-lactone, allohydroxycitric-acid, glycolic acid, utalonic acid, protocatechuic acid, cyanidin-3glucoside, cyanidin-3-sambubioside, cyanidin-3 - xyloglucoside, delphinidin, delphinidin-3glucoside, delphinidin-3sambubioside, delphinidin-3xyloglucoside, delphinin, gossypetin, gossypetin-3-glucoside, hibiscetin, hibiscin, hibiscitrin, sabdaretin, sabdaritrin, fibre (crude), resin, fibre (dietery), minerals and ash.

Seed

Starch, cholesterol, cellulose, carbohydrates, campesterol, $\beta$ sitosterol, ergosterol, propionic acid, pentosans, pelargonic acid, palmitoleic acid, palmitic acid, oleic acid, myristic acid, methanol, malvalic acid, linoleic acid, sterculic acid, caprylic acid, formic acid, stearic acid, cis-12,13-epoxy-cis-9octadecenoic acid, isopropyl alcohol, isoamyl alcohol, ethanol, 3-methyl1 - butanol, fibre and minerals. 
Leaf

Fruit

\section{Root}

$\alpha$-Terpinyl acetate, anisaldehyde, $\beta$ carotene, $\beta$-sitosterol, $\beta$-Dgalactoside, $\beta$-sitosteryl benzoate, niacin, fat, isoamyl alcohol, isopropyl alcohol, methanol, 3-methyl1-butanol, benzyl alcohol, ethanol, malic acid, fibre and ash.

$\alpha$-Terpinyl acetate, pectin, anisaldehyde, ascorbic acid, calcium oxalate, caprylic acid, citric acid, acetic acid, ethanol, formic acid, pelargonic acid, propionic acid, isopropyl alcohol, methanol, benzyl alcohol, 3-methyl-1- butanol, benzaldehyde and minerals

Adapted from (7)

\section{Nutritional value of HS calyces}

The reported nutritional value of HS calyces differs between studies (see table 2). These differences could result from the variety of HS, soil type, harvesting and processing practices employed (3).

\section{Organic acid content of HS calyces}

HS contain a high percentage of organic acids including citric acid, hydroxycitric acid, hibiscus acid, malic and tartaric acids as major organic acids and oxalic and ascorbic acid as minor organic acids (7). The ascorbic acid content in the calyces varies between fresh (6.7$1.4 \mathrm{mg} / 100 \mathrm{~g})(2)$ and dried calyces $(260-280 \mathrm{mg} / 100 \mathrm{~g})$ (14).

Table 2: Nutritional composition of HS calyces

\begin{tabular}{lll}
\hline Nutrients & $(\mathbf{1 9 )}$ & $(14)$ \\
\hline Protein & $1.145 \mathrm{~g} / 100 \mathrm{~g}$ & $1.9 \mathrm{~g} / 100 \mathrm{~g}$ \\
Fat & $2.61 \mathrm{~g} / 1 \mathrm{OOg}$ & $0.1 \mathrm{~g} / 100 \mathrm{~g}$ \\
Fibre & $12.0 \mathrm{~g} / 100 \mathrm{~g}$ & $2.3 \mathrm{~g} / 100 \mathrm{~g}$ \\
Ash & $6.90 \mathrm{~g} / 100 \mathrm{~g}$ & $*$ \\
Calcium & $12.63 \mathrm{mg} / 100 \mathrm{~g}$ & $1.72 \mathrm{mg} / 100 \mathrm{~g}$ \\
Phosphorus & $273.2 \mathrm{mg} / 100 \mathrm{~g}$ & $*$ \\
Iron & $8.98 \mathrm{mg} / 100 \mathrm{~g}$ & $57 \mathrm{mg} / 100 \mathrm{~g}$ \\
Carotene & $0.029 \mathrm{mg} / 100 \mathrm{~g}$ & $300 \mu \mathrm{g} / 100 \mathrm{~g}$ \\
Thiamine & $0.117 \mathrm{mg} / 100 \mathrm{~g}$ & $*$ \\
Riboflavin & $0.277 \mathrm{mg} / 100 \mathrm{~g}$ & $*$ \\
Niacin & $3.765 \mathrm{mg} / 100 \mathrm{~g}$ & $*$ \\
Ascorbic acid & $6.7 \mathrm{mg} / 100 \mathrm{~g}$ & $14 \mathrm{mg} / 100 \mathrm{~g}$ \\
Carbohydrates & $*$ & $12.3 \mathrm{~g} / 100 \mathrm{~g}$ \\
\hline *- not reported & &
\end{tabular}

$*=$ not reported
Hydroxycitric acid, hibiscus acid and its derivatives are the principal organic acids found in the calyces and leaves (20). The hydroxycitric acid in HS calyces is the $(+)$ - hydroxycitric acid also known as (+)-HCA (21). Its Isomer (-)-HCA is an inhibitor of citrate lyase (22) and has been proposed as an anti-obesity agent $(22,23)$. In rats, hydroxycitric acid in HS calyx extract inhibits fat production from carbohydrates (24). It has been suggested that racemization of (+)-HCA to (-)-HCA by the intestinal flora may be an explanation to warrant the significant decrease in triacylglycerols in the experiment carried out on rats supplemented with HS calyx extracts (25).

\section{Anthocyanin content of HS}

The anthocyanins are a group of flavonoid derivatives and natural pigments present in the dried flowers of HS whose (anthocyanins) colour varies with $\mathrm{pH}$ (3). These pigments have been researched extensively because of their recognized antioxidant activity (20).

Yamamoto and Oshima (26) identified the first anthocyanin from the calyces of HS "hibiscin" or "hiviscin" to which they assigned the structure cyanidin3 -glucoside and then later renamed it to delphinidinpentoside-glucoside (27). Other anthocyanins including delphinidin-3-glucoside, cyanidin-3-glucoside $(28,29)$ and cyanidin-3-sambubioside (gossipicyanin) (29) were also identified. Subramanian and Nair (30) reported the presence of cyanidin-3, 5-diglucoside and cyanidin-3(2G-glucosylrutinoside) in the flower pigments of $H S$.

Several studies identified delphinidin-3-sambubioside and cyanidin-3-sambubioside as the major anthocyanins in HS calyx extracts $(20,31)$

\section{Flavonoid content of HS}

HS contains simple and polymerised forms of polyphenolic compounds (3). Hibiscitrin, sabdaritrin, gossypitrin, gossytrin, quarcetin, luteolin, chlorogenic acid, procatechuic acid, pelagonidic acid and eugenol have been described in HS extracts (32). AlarconAlonso, Zamilpa (31) reported that the amount of quercetin present in the aqueous extracts of HS calyces was $3.2 \mathrm{mg} / \mathrm{g}$ while rutin was $2.1 \mathrm{mg} / \mathrm{g}$. Quercetin and its conjugated glycosides as well as rutin were also identified in aqueous extracts of HS calyces together with kaempferol (20).

Aqueous calyx extracts of HS showed the presence of procatechuic acid (24.24\%), catechin (2.67\%), 
gallocatechin (2.44\%), caffeic acid (19.85\%) and gallocatechin gallate (27.98\%) (33).

Procatechuic acid (PCA), an important phenolic acid in the calyces of HS (32) has been found to inhibit skin tumour promotion in mouse (34). HS calyces and leaves contain chlorogenic acid; a phenolic (35) which belongs to a family of esters formed between certain transcinnamic and quinic acids (36). The amount of chlorogenic acid in HS extract was reported to be $2.7 \mathrm{mg} / \mathrm{g}(31)$.

\section{Polysaccharide content of $H S$}

Polysaccharides are present in large quantities in HS. Müller and Franz (37) reported a yield of 10\% reddish polysaccharides from ethanol-precipitated water extracts of HS calyces. Arabinose, galactose, glucose, rhamnose and smaller amounts of mannose and xylose were identified in two different fractions (38). The petals of HS yielded 65\% (dry weight) of mucilage which yielded galactose, and rhamnose on hydrolysis (39).

\section{Pharmacology and biological activity of $H S$}

HS has been used in folk medicine in the treatment of many conditions and most of these folkloric claims have been verified scientifically.

\section{Anti-obesity and hypolipidemic effects}

The persistent increase in the global incidence of obesity is worrisome especially as it increases the risk of developing metabolic dysfunction (40). HS has been proved to hold prospects in the prevention and treatment of obesity.

Alarcon-Aguilar, Zamilpa (6) induced obesity in mice using monosodium glutamate (MSG) and then administered $H S$ aqueous extracts for 60 days $(33.64 \mathrm{mg}$ of total anthocyanins per $120 \mathrm{mg}$ of extract) to healthy and obese mice. They observed significantly reduced body mass gain in obese mice and increased liquid intake in obese and healthy mice. While investigating the effects of HS ethanol extracts on fat-absorption-excretion and body weight in rats, Carvajal-Zarrabal, Hayward-Jones (25) concluded that components of $H S$ at intermediate and greater concentrations could serve as anti-obesity agents. These anti-obesity effects could be as a result of the modification of the P13-K/Akt and ERK pathway which plays a vital role in adipogenesis (41).

Lin, Lin (42) investigated the effects of HS extract on serum cholesterol in human subjects and found that serum cholesterol was significantly reduced in subjects that took 2 capsules (1g) of HS extract for a month suggesting that HS extracts may be effective in hypercholesterolemic patients. HS was also found to inhibit serum lipids and to show anti-atherosclerotic activity (43). On histology, they found HS to reduce foam cells formation and inhibit smooth muscle cell migration and calcification in the blood vessels of rabbits. HSE powder significantly reduced glucose and total cholesterol levels, increased TAG/HDL-c ratio, a marker of insulin resistance (44).

A reduction was observed in the levels of LDL and the ratio of LDL-c to HDL-c when HS extracts were administered to high fructose-fed and high cholesterolfed rats; suggesting that it may be used to inhibit LDL oxidation and to prevent various types of hyperlipidaemia in high fructose-fed and high cholesterol- fed rats (45). Aqueous calyx extracts of HS inhibit the accumulation of triglycerides better when the fibre and polysaccharide components have been removed (20). HS-derived polyphenols are known to ameliorate various obesity-related conditions. Recent studies suggest a complex underlying mechanism of action which involves the regulation of energy metabolism, oxidative stress and inflammatory pathways, transcription factors, hormones and peptides, digestive enzymes, as well as epigenetic modifications (46).

\section{Antihypertensive and cardioprotective effects}

Hypertension contributes significantly to the global burden of non-communicable diseases and is responsible for a lot of morbidities and mortalities (47). Annually, hypertension accounts for about $13 \%$ of deaths globally (48). HS has been shown to have anti-hypertensive effects in animal $(11,49)$ and human $(32,50)$. Its antihypertensive effect is thought to be mediated via a direct vaso-relaxant effect (51) diuretic (52), calcium ion channels modulation (53) and the inhibition of angiotensin converting enzyme by the anthocyanins (10).

$H S$ has been found to exhibit cardio-protective activity by enhancing myocardial capillarization in spontaneously hypertensive rats that were orally fed its aqueous calyx extracts (49) and by reversing cardiac hypertrophy in $2 \mathrm{~K}-1 \mathrm{C}$ (2Kidneys, 1 clip) hypertensive rats (54). HS polyphenols were shown to exhibit negative inotropic, negative chronotropic and positive ionotropic responses, possibly by modulating calcium entry, release and reuptake in the heart. This suggests that HS 
polyphenols are potential candidates for the treatment of conditions like arrhythmia (55).

\section{Anti-diabetic effects}

Diabetes mellitus is an endocrine disorder associated with hyperglycaemia, dyslipidaemia and results from defects in insulin secretion and/or action (56). Globally, diabetes mellitus is a highly prevalent disease responsible for high morbidity and mortality (57). When HS polyphenolic extract was administered to a type 2 diabetic rat model at a dose of $200 \mathrm{mg} . \mathrm{kg}-1$ it reduced hyperglycaemia, hyperinsulinaemia, advanced glycation end product and lipid peroxidation (57). HS was shown to be a potent inhibitor of pancreatic $\alpha$-amylase (58). The inhibition of pancreatic $\alpha$-amylase and intestinal $\alpha$ glucosidase slows down the digestion of carbohydrates to more absorbable monosaccharides; a therapeutic strategy currently in vogue for the control of post prandial hyperglycaemia (58). The hypolipidemic and antioxidant properties of HS ethanolic extract were confirmed in alloxan-induced diabetic rats (59) where they showed therapeutic potentials in preventing the development of atherosclerosis and other cardiovascular complications associated with diabetes.

HS calyx extract palliates insulin resistance, hyperglycaemia, dyslipidaemia and oxidative stress in high- fructose- induced metabolic syndrome rats (60). The calyx extract was also demonstrated to inhibit 3 key enzymatic targets $(\alpha-/ \beta$-glucosidase and $\alpha$-amylase) in antidiabetic therapy (61).

\section{Antioxidant effects}

Antioxidants protect the tissues from peroxidative damage (62). Several studies have reported the antioxidant activity of HS (63, 64). This antioxidant activity is expressed in different ways and by both aqueous and ethanolic extract of the calyces, seeds and leaves (63). The extract can exert their antioxidant action by scavenging free radicals and reactive oxygen species (65), inhibition of xanthine oxidase activity (34) and prevention of cell damage via lipid peroxidation (65). HS extracts also inhibit the formation of malondialdehyde (65) and oxidation of low-density lipoprotein and formation of thiobarbituric reactive substances (TBARS) by $\mathrm{Cu} 2+(66)$. HS could reduce glutathione depletion and also alter the activities of superoxide dismutase and catalase in the liver and blood (67).

HS calyx extract attenuates high-fructose diet-mediated decreases in the activities of superoxide dismutase (SOD), catalase (CAT), glutathione peroxidase (GSH$\mathrm{Px}$ ), glutathione reductase (GSH-red) and glucose 6phosphate dehydrogenase (G6PD) and also brings down the increased levels of malondialdehyde, conjugated dienes, lipid hydroperoxides, protein carbonyl and percentage fragmented DNA induced by high-fructose $\operatorname{diet}(60)$.

\section{Hepatoprotective effects}

Lee, Kuo (68) found that pre-treatment with a polyphenolic extract of HS protected the liver from acetaminophen-induced liver injury in BALB/c mice. The extracts increased the level of glutathione, decreased the level of peroxidation and increased catalase activity in the liver.

HS also reduced liver steatosis and fibrosis, decreased the elevation of aspartate aminotransferase (AST) and alanine aminotransferase (69). During Carbon tetrachloride $(\mathrm{CCl} 4)$ treatment, HS extracts restored the decrease in glutathione content and inhibited lipid peroxidation (69).

HS aqueous extract was found to reduce body mass gain and protect the liver by reducing fat accumulation, attenuating steatosis, down-regulating sterol regulatory element binding protein (SREBP-1c) and peroxisome proliferator- activated receptor gamma (PPAR- $\gamma$ ), blocking the increase of interleukin one (IL-1), tumour necrosis factor alpha messenger ribonucleic acid (TNF- $\alpha$ mRNA), lipoperoxidation and increasing catalase mRNA in obese C57BL/6NHsd mice (40).

HS calyx extract causes significant reduction in serum levels of alanine aminotransferase, aspartate aminotransferase and hepatic malondialdehyde (70). Furthermore, it decreases the immunopositivity of nuclear factor kappa-B and CYP2E1 in the liver, with an increase in the effector apoptotic marker (caspase-3 positive cells) and restoration of the altered hepatic architecture (70).

\section{Nephroprotective effects}

Most often, diabetic nephropathy progresses to end stage renal disease, and this is thought to be mediated by oxidative stress (71). Phenolic extracts of HS reduced the kidney mass and improved the hyperglycaemia-induced osmotic diuresis in the proximal tubules while significantly lowering the serum triglyceride, total cholesterol, LDL and increasing the activity of catalase, 
glutathione and reducing lipid peroxidation in streptozotocin-induced diabetic rats (71). These findings were in agreement with those of Wang, Lee (72). The latter proposed that the observed HS extracts nephroprotective effects might involve the up-regulation of Akt/Bad/14-3-3 $\gamma$ and nuclear factor-kappa B (NF-kB)mediated transcription. In a study on the effects of HS calyces on creatinine and serum electrolytes, no significant harmful changes were observed in blood urea nitrogen (BUN), serum creatinine, sodium and potassium levels (73).

HS palliates lipopolysaccharide-induced renal inflammation via downregulation of cytokine network, pro-inflammatory product production, and nuclear factor- $\kappa \mathrm{B}(\mathrm{NF}-\kappa \mathrm{B})$ pathway (74).

The adverse effects of adenine- induced chronic kidney disease (CKD) significantly decreased in rats, when either HS aqueous calyx extract or its anthocyanins were administered along with adenine indicating that they may be safe dietary agents that could be used to attenuate the progression of human CKD (75).

\section{Anti-cancer effects}

HS protocatechuic acid was found to inhibit the 12-Otetradecanoylphorbol-13-acetate (TPA)-induced promotion in skin tumours of female CD-1 mice (34). The topical application of protocatechuic acid twice weekly prior to TPA treatment inhibited the incidence of tumours in mice significantly while all the mice that were not treated developed the tumour.

HS aqueous calyx extract caused a 91\% reduction in micronucleus frequency and protected against cyclophosphamide-induced damage to DNA (76). Methanolic calyx extract of HS was demonstrated to have potent inhibitory effect against Ehrlich ascites carcinoma cells with a half maximal inhibitory concentration of $28.16 \mu \mathrm{g} / \mathrm{mL}(77)$.

\section{Anti-pyretic and analgesic effects}

HS calyx aqueous and ethanolic extracts were investigated for their nociceptive, anti-inflammatory and anti-pyretic effects using the writhing, hot plate and formalin tests in mice; yeast-induced fever and carrageenan-induced paw oedema in rats respectively (78). The ethanol and vacuum dried extracts of HS (200$800 \mathrm{mg} . \mathrm{kg}-1$ ) reduced the yeast-induced fever but had no effect on the other tests suggesting that HS calyx extracts have anti-pyretic effects through mechanisms different from those of aspirin (78).

Antinociceptive activity of ethanolic calyx extract of HS was evaluated by using the acetic acid-induced writhing test. The anti-inflammatory effect of the extract was tested by using the xylene-induced ear oedema model mice. There was a significant inhibition of writhing in the mice when compared with the blank control. This indicates that the calyx extract possesses significant antinociceptive, anti-inflammatory (79). In another study, HS calyx extract showed significant analgesic effect in a rat model (80).

\section{Sexual maturity and lactogenic effects}

HS aqueous extract administered to pregnant Sprague Dawley rats resulted in post-natal weight gain in the pups, delayed onset of puberty in the female offspring and increased body mass index through mechanisms that may be linked to glucocorticoid and leptin signalling (17). In a lactogenic study on the seeds of HS, an elevation was found in the serum prolactin levels of Albino Wistar rats in a dose dependent manner with the maximum effect occurring at doses of $800 \mathrm{mg} \cdot \mathrm{kg}-1$ and 1600mg.kg-1 (81, 82).

HS ameliorated cadmium-induced reduction in testicular weight in rats, and also reduction in activities of catalase (CAT) and superoxide dismutase (SOD) and levels of reduced glutathione (GSH) in the testes of the rats (83).

HS aqueous calyx extract was shown to cause progressive increase in milk production reaching its peak in the third week during lactation in experimental animals (84).

\section{Anti-bacterial/antimicrobial effects}

Methanolic extracts of HS were studied for their antimicrobial effects in vitro using a disc-diffusion method. The extracts exhibited activities comparable to that of streptomycin against various clinically important gram positive and gram-negative bacteria such as Staphylococcus aureus, Micrococcus luteus, Clostridium sporogens, Escherichia coli, Klebsiella pneumonaie, Bacillus cereus and Pseudomonas fluorescence (85). Fullerton, Khatiwada (86) investigated the antimicrobial effects of HS calyces against Escherichia coli O157:H7 found in food, veterinary and clinical samples. The calyx extracts of HS exhibited antimicrobial action against Escherichia coli at 2.5\%,5\% and $10 \%$ concentrations 
(87).

\section{Effects on smooth muscles}

An aqueous extract of the petals of HS was shown to have a vaso-relaxant effect on rat aortic rings through endothelium-dependent and independent mechanisms (88). Fouda, Mohamad (89) reported an inhibition of rat bladder and uterine contractility by an aqueous calyx extract of HS through mechanisms unrelated to local or remote autonomic receptors or calcium channels as previously suggested in a study of the effects of HS on the $\operatorname{GIT}(90,91)$.

\section{Haematinic effects}

The dried fermented calyces of HS have a very low $\mathrm{pH}$ (3.2) which increases the bioavailability of other minerals such as iron and calcium (92). The high ascorbic content of HS calyces could also be responsible for an increase in the bioavailability of other minerals including iron which are essential for erythropoiesis (92). There may therefore be a role for HS in iron supplementation in the prevention or treatment of anaemia. Adigun, Ogundipe (93) studied the effects of HS extracts on some haematological parameters in Wistar albino rats. After 14 days of HS oral administration, a significant elevation of haematocrit and haemoglobin in the groups that received low doses of the extract (200mg.kg-1 body wt. and 400mg.kg-1 body wt.) was observed while the groups that received higher doses had significant reduction in haematocrit but not haemoglobin concentration (94).

\section{Other effects}

HS aqueous extracts were shown to possess diuretic and natriuretic properties via the compound quercetin which causes the vascular endothelium to release nitric oxide and cause renal vasodilation and increased kidney filtration in rats (31). HS extracts were also suggested as a valuable ethnomedicine in the management of chronic inflammatory diseases because of its ability to modulate the production of monocyte chemoattractant protein-1 (95). This immunomodulatory action might be both cell and humoral mediated (96). There is also evidence for use of aqueous dried calyx extracts as an anti-diarrhoeal agent as it was found to increase transit time and reduce intestinal motility in rats (97).

In a study to examine the staining effect of methanolic extract of HS calyx on thin peripheral blood films, it impacted a poor pale pinkish-orange coloration with pseudo large pallor on red blood cell in thin peripheral blood smear (98).

\section{Conclusion}

HS is a wonder plant with a lot of beneficial health effects and almost no side effects. These beneficial effects are as a result of the large number of phytochemicals that are loaded in the plant. Therefore, more clinical trials are needed to validate these beneficial effects with a view to implementing them for the benefit of patients.

\section{Acknowledgement}

The authors acknowledge the guidance of Associate Professors Kennedy Erlwanger and Eliton Chivandi of the University of the Witwatersrand, Johannesburg.

\section{References}

1. Maganha EG, Halmenschlager RDC, Rosa RM, Henriques JaP, Ramos ALLDP, Saffi J. Pharmacological evidences for the extracts and secondary metabolites from plants of the genus Hibiscus. Food Chem. 2010;118(1):1-10

2. Julia F. In : Fruits of warm climate edited by Morton J, Miami, 281286. Morton JF, editor 1987.

3. Da-Costa-Rocha I, Bonnlaender B, Sievers H, Pischel I, Heinrich M. Hibiscus sabdariffa L. - A phytochemical and pharmacological review. Food Chem. 2014;165(0):424-43.

4. Gautam RD. Sorrel- A lesser known source of medicinal food drink and food in India. Nat. Prod. Rad. 2004;3(5):338-42.

5. Pfeil B, Crisp M. What to do with Hibiscus? A proposed nomenclatural resolution for a large and well known genus of Malvaceae and comments on paraphyly. Aust. Syst. Bot. 2005;18(1):49-60.

6. Alarcon-Aguilar FJ, Zamilpa A, Perez-Garcia MD, Almanza-Perez JC, Romero-Nunez E, Campos-Sepulveda EA, et al. Effects of Hibiscus sabdariffa on obeisity in MSG mice. J Ethnopharmacol. 2007; 114:66-71

7. Mahadevan N, Shivali, Kamboj P. Hibiscus sabdariffa Linn: An overview. Nat. Prod. Rad. 2009;8(1):77-83.

8. Riaz G, Chopra R. A review on phytochemistry and therapeutic uses of Hibiscus sabdariffa L. Biomed. Pharmacother. 2018;102:575-86.

9. Herrera- Arellano A, Flores- Romero S, Chavez- Soto MA, Tortoriello J. Effectiveness and tolerability of a standardized extract from Hibiscus sabdariffa in patients with mild to moderate hypertension: A controlled and randomized clinical trial. Phytomedicine 2004;11:37582 .

10. Ojeda D, Jiminez-Ferrer E, Zamilpa A, Herrera-Allerano A, Jaime T, Alvarez L. Inhibition of angiotensin converting enzyme activity by the anthocyanins delphinidin and cyaniding- 3- O- Sambubiosides from Hibiscus sabdariffa. J Ethnopharmacol. 2010;127:7-10.

11. Mojiminiyi FBO, Audu Z, Etuk EU, Ajagbonna OP. Attenuation of salt-induced hypertension by aqueous calyx extract of Hibiscus Sabdariffa Nig. J. Physiol. Sci. 2012:195-200.

12. Patel S. Hibiscus sabdariffa: An ideal yet under-exploited candidate for nutraceutical applications. Biomed. Prevent. Nutr. 2014;4(1):23-7.

13. Leung A, Foster S. Encyclopedia of Common Natural Ingredients 
Used in Food, Drugs and Cosmetics 2nd Edition. 2nd ed. New York: John Wiley and sons; 1996.

14. Ismail A, Ikram EHK, Nazri HSM. Roselle (Hibiscus sabdariffa L.) seeds nutritional composition, protein quality and health benefits. Food. 2008;2(1):1-16.

15. Wilson FD, Menzel MY. Kenaf (Hibiscus cannabinus), roselle (Hibiscus sabdariffa). Econ. Bot. 1964;18(1):80-91.

16. Atta MB, Imaizumi K. Some characterisitcs of Crude Oil extracted from Roselle (Hibiscus sabdariffa L) seeds cultivated in Egypt. JOleo Sci. 2002;51(7):457-61.

17. Gaya I, Mohammad O, Suleiman A, Maje M, Adekunle A. Toxicological and lactogenic studies on the seeds of Hibiscus sabdariffa linn (Malvaceae) extract on serum prolactin levels of albino wistar rats. J. Endocrinol. 2009;5(2).

18. Al Snafi AE. Pharmacological and therapeutic importance of A review. Int. J. Pharm. Res. 2018;10(3)

19. Mahadevan N, Shivali, Kamboj P. Hibiscus sabdariffa Linn: An overview. Nat. Prod. Rad. 2009;8(1):77-83.

20. Herranz-López M, Fernández-Arroyo S, Pérez-Sanchez A, BarrajónCatalán E, Beltrán-Debón R, Menéndez JA, et al. Synergism of plantderived polyphenols in adipogenesis: Perspectives and implications. Phytomedicine. 2012;19(3-4):253-61.

21. Yamada T, Hida H, Yamada Y. Chemistry, physiological properties, and microbial production of hydroxycitric acid. Appl Microbiol Biotechnol. 2007;75(5):977-82

22. Sullivan A, Triscari J, Hamilton J, Miller ON, Wheatley V. Effect of (-)-hydroxycitrate upon the accumulation of lipid in the rat: I. Lipogenesis. Lipids. 1974;9(2):121-8.

23. Hayamizu K, Ishii Y, Kaneko I, Shen M, Okuhara Y, Shigematsu N, et al. Effects of garcinia cambogia (Hydroxycitric Acid) on visceral fat accumulation: a double-blind, randomized, placebo-controlled trial. Curr. Ther. Res. 2003;64(8):551-67.

24. Tee P-L, Yusof S, Mohamed S, Umar NA, Mustapha NM. Effect of roselle (Hibiscus sabdariffa L.) on serum lipids of Sprague Dawley rats. Nutr. Food Sci. 2002;32(5):190-6.

25. Carvajal-Zarrabal O, Hayward-Jones P, Orta-Flores Z, NolascoHipólito C, Barradas-Dermitz D, Aguilar-Uscanga M, et al. Effect of Hibiscus sabdariffa L. dried calyx ethanol extract on fat absorptionexcretion, and body weight implication in rats. BioMed. Res. Int. 2009;2009:Article ID 394592, 5 pages doi:10.1155/2009/.

26. Yamamoto R, Oshima Y. On the red colouring matter of Hibiscus sabdariffa L.(A new glycoside Hibiscin). Scientific Papers of the Institute of Physical and Chemical Research (Tokyo). 1932;19:13441

27. Yamamoto R, Oshima Y. Coloring matter of Hibiscus sabdariffa L.(Hibiscin). Scientific Papers of the Institute of Physical and Chemical Research (Tokyo). 1936;30:258-62.

28. Du C, Francis F. Anthocyanins of roselle (Hibiscus sabdariffa, L.). J Food Sci. 1973;38(5):810-2

29. Shibata M, Furukawa M. Reexamination on the structure of so-called" hiviscin". Botanical Magazine Tokyo. 1969:10-5.

30. Subramanian SS, Nair A. Flavonoids of four Malvaceous plants. Phytochemistry. 1972;11(4):1518-9.

31. Alarcon-Alonso J, Zamilpa A, Alarcon-Aguilar F, Herrera-Ruiz M, Tortoriello J, Jiminez-Ferrer E. Pharmacological characterization of the diuretic effect of Hibiscus sabdariffa Linn (Malvaceae) extract. $J$
Ethnopharmacol. 2012;139:751-6.

32. Mckay D. Can hibiscus tea lower blood pressure. Agro Food Industry Hi-Tech. 2009;20(6):40-2

33. Yang $M$-Y, Peng $C-H$, Chan $K-C$, Yang $Y-S$, Huang $C-N$, Wang $C$-J. The Hypolipidemic Effect of Hibiscus sabdariffa Polyphenols via Inhibiting Lipogenesis and Promoting Hepatic Lipid Clearance. J. Agr. Food Chem. 2009;58(2):850-9.

34. Tseng T-H, Hsu J-D, Lo M-H, Chu C-Y, Chow F-P, Hwang C-L, et al. Inhibitory effects of Hibiscus protocatechuic acid on tumour promotion in mouse skin. Cancer Lett. 1998;126:199-207.

35. Ramirez-Rodrigues MM, Plaza ML, Azeredo A, Balaban MO, Marshall MR. Physicochemical and Phytochemical Properties of Cold and Hot Water Extraction from Hibiscus sabdariffa. J Food Sci. 2011;76(3):C428-C35

36. Clifford MN, Johnston KL, Knight S, Kuhnert N. Hierarchical Scheme for LC-MSn Identification of Chlorogenic Acids. J. Agr. Food Chem. 2003;51(10):2900-11.

37. Müller BM, Franz G. Chemical Structure and Biological Activity of Polysaccharides from Hibiscus sabdariffa. Planta Med. 1992;58(01):60-7.

38. Brunold C, Deters A, Knoepfel-Sidler F, Hafner J, Müller B, Hensel A. Polysaccharides from Hibiscus sabdariffa flowers stimulate proliferation and differentiation of human keratinocytes. Planta Med. 2004;70(04):370-3.

39. El-Hamidi A, Saleh M, Ahmed S, editors. Hibiscus sabdariffa. Chemical Abstracts; 1967.

40. Villalpando-Arteaga EV, Mendieta-Condado † E, Esquivel-Solís $H$, Canales-Aguirre AA, Gálvez-Gastélum FJ, Mateos-Díaz JC, et al. Hibiscus sabdariffa L. aqueous extract attenuates hepatic steatosis through down-regulation of PPAR- $\gamma$ and SREBP-1c in diet-induced obese mice. Food Funct. 2013;4:618-26.

41. Kim J-K, So H, Youn M-J, Kim H-J, Kim Y, Park C, et al. Hibiscus sabdariffa $L$. water extract inhibits the adipocyte differentiation through the PI3-K and MAPK pathway. $J$ Ethnopharmacol. 2007:114(2):260-7

42. Lin T-L, Lin H-H, Chen C-C, Lin M-C, Chou M-C, Wang C-J. Hibiscus sabdariffa extract reduces serum cholesterol in men and women. Nutr Res. 2007;27(3):140-5.

43. Chen C-C, Hsu J-D, Wang S-F, Chiang H-C, Yang M-Y, Kao E$S$, et al. Hibiscus sabdariffa extract inhibits the development of atherosclerosis in cholesterol-fed rabbits. J. Agr. Food Chem. 2003;51(18):5472-7.

44. Gurrola-Daiz CM, Garcia-Lopez PM, Sanchez Enriquez S, Troyo-Sanroman R, Andrade-Gonzalez T, Gomez-Leyva J. Effects of Hibiscus sabdariffa powder and preventive treatment (diet) on the lipid profiles of patients with metabolic syndrome. Phytomedicine 2010;17:500-5.

45.Chen C-C, Chou F-P, Ho Y-C, Lin W-L, Wang C-P, Kao E-S, et al. Inhibitory effects of Hibiscus sabdariffa L extract on Low density lipoprotein oxidation and anti-hyperlipidemia in fructose fed and cholesterol fed rats. J. Sci. Food Agric. 2004;84:1989-96.

46. Herranz-López M, Olivares-Vicente M, Encinar J, Barrajón-Catalán E, Segura-Carretero A, Joven J, et al. Multi-targeted molecular effects of Hibiscus sabdariffa polyphenols: An opportunity for a global approach to obesity. Nutrients. 2017;9(8):907.

47. Wahabi HA, Alansary LA, Al-Sabban AH, Glasziuo P. The effectiveness of Hibiscus sabdariffa in the treatment of hypertension: A systematic 
review. Phytomedicine. 2010;17(2):83-6.

48. Brown MJ. Science, medicine, and the future. Hypertension. BMJ: Brit. Med.J. 1997;314(7089):1258.

49. Inuwa I, Ali BH, Al-Lawati I, Beegam S, Ziada A, Blunden G. Longterm ingestion of Hibiscus sabdariffa calyx extract enhances myocardial capillarization in the spontaneously hypertensive rat. Exp. Biol. Med. 2012;237(5):563-9.

50. Mozaffari-Khosravi H, Jalali-Khanabadi BA, Afkhami-Ardekani M, Fatehi F, Noori-Shadkam. The effects of sour tea (Hibiscus sabdariffa) on hypertension in patients with type 2 diabetes mellitus. J Human Hypertens 2009;23:48-54

51. Ali BH, Wabel NA, Blunden G. Phytochemical, pharmacological and toxicological aspects of Hibiscus sabdariffa L.: a review. Phytother Res. 2005;19(5):369-75.

52. Mojiminiyi FBO, Adegunloye BJ, Egbeniyi YA, Okolo RU. An investigation of the diuretic effect of an aquoeus calyx extract of Hibiscus sabdariffa. J. Med. Med. Sci. 2000;2:77-80.

53. Owolabi $O$, Adegunloye B, Ajagbona $O$, Sofola $O$, Obiefuna $P$. Mechanism of relaxant effect mediated by an aqueous extract of Hibiscus sabdariffa petals in isolated rat aorta. Pharm Biol. 1995;33(3):210-4.

54. Odigie IP, Ettarh RR, Adigun SA. Chronic administration of aqueous extract of Hibiscus sabdariffa attenuates hypertension and reverses cardiac hypertrophy in $2 \mathrm{~K}-1 \mathrm{C}$ hypertensive rats. J. Ethnopharmacol. 2003;86(2-3):181-5.

55. Lim YC, Budin SB, Othman F, Latip J, Zainalabidin S. Roselle Polyphenols Exert Potent Negative Inotropic Effects via Modulation of Intracellular Calcium Regulatory Channels in Isolated Rat Heart. Cardiovasc. Toxicol. 2017;17(3):251-9.

56. Alberti KGMM, Zimmet PF. Definition, diagnosis and classification of diabetes mellitus and its complications. Part 1: diagnosis and classification of diabetes mellitus. Provisional report of a WHO consultation. Diabetic Med. 1998;15(7):539-53.

57. Peng C-H, Chyau C-C, Chan K-C, Chan T-H, Wang C-J, Huang C-N. Hibiscus sabdariffa Polyphenolic Extract Inhibits Hyperglycemia, Hyperlipidemia, and Glycation-Oxidative Stress while Improving Insulin Resistance. J. Agri. Food Chem. 2011;59(18):9901-9.

58. Adisakwattana S, Ruengsamran T, Kampa P, Sompong W. In vitro inhibitory effects of plant-based foods and their combinations on intestinal alpha-glucosidase and pancreatic alpha-amylase. BMC Complement. Altern. Med. 2012;12(1):110

59. Farombi E, Ige O. Hypolipidemic and antioxidant effects of ethanolic extract from dried calyx of Hibiscus sabdariffa in alloxan- induced diabetic rats. Fundam. Clin. Pharmacol. 2007;21(6):601-9.

60. Ajiboye TO, Raji HO, Adeleye AO, Adigun NS, Giwa OB, Ojewuyi OB, et al. Hibiscus sabdariffa calyx palliates insulin resistance, hyperglycemia, dyslipidemia and oxidative rout in fructose-induced metabolic syndrome rats. J Sci Food Agric. 2016;96(5):1522-31.

61. Marisca EG, Hanna SWK, Wahyu $W$. $\alpha$-/ $\beta$-Glucosidase and $\alpha$-Amylase Inhibitory Activities of Roselle (Hibiscus sabdariffa L.) Ethanol Extract. Mol. Cell. Biomed. Sci. 2017;1(1):34-40.

62. Olaleye MT. Cytotoxicity and antibacterial activity of methanolic extract of Hibiscus sabdariffa. J. Med. Plant Res. 2007;1(1):009-13.

63. Mohd-Esa N, Hern FS, Ismail A, Yee CL. Antioxidant activity in different parts of roselle (Hibiscus sabdariffa L.) extracts and potential exploitation of the seeds. Food Chem. 2010;122(4):1055-60.

64. Mossalam HH, Abd-El Aty OA, Morgan EN, Youssaf SM, Mackawy
AMH. Biochemical and Ultra Structure Studies of the Antioxidant Effect of Aqueous Extract of Hibiscus Sabdariffa on the Nephrotoxicity Induced by Organophosphorous Pesticide (Malathion) on the Adult Albino Rats. J. Am. Sci. 2011;7(12):407-21.

65. Farombi EO, Fakoya A. Free radical scavenging and antigenotoxic activities of natural phenolic compounds in dried flowers of Hibiscus sabdariffa L. Mol. Nutr. Food Res. 2005;49(12):1120-8.

66. Hirunpanich V, Utaipat A, Morales NP, Bunyapraphatsara N, Sato H, Herunsalee A, et al. Antioxidant effects of aqueous extracts from dried calyx of Hibiscus sabdariffa Linn.(Roselle) in vitro using rat lowdensity lipoprotein (LDL). Biol. Pharm. Bull. 2005;28(3):481-4.

67. Usoh I, Akpan E, Etim E, Farombi E. Antioxidant actions of dried flower extracts of Hibiscus sabdariffa L. on sodium arsenite-induced oxidative stress in rats. Pak. J. Nutr. 2005;4(3):135-41.

68. Lee C-H, Kuo C-Y, Wang C-J, Wang C-P, Lee Y-R, Hung C-N, et al. A Polyphenol Extract of Hibiscus sabdariffa $L$. Ameliorates Acetaminophen-Induced Hepatic Steatosis by Attenuating the Mitochondrial Dysfunction in Vivo and in Vitro. Biosci. Biotech. Biochem. 2012;76(4):646-51.

69. Liu J-Y, Chen C-C, Wang W-H, Hsu J-D, Yang M-Y, Wang C-J. The protective effects of Hibiscus sabdariffa extract on CCL4-induced liver fibrosis in rats. Food Chem. Toxicol. 2006;44:336-43.

70. Ezzat SM, Salama MM, Seif El-Din SH, Saleh S, El-Lakkany NM, Hammam $O A$, et al. Metabolic profile and hepatoprotective activity of the anthocyanin-rich extract of Hibiscus sabdariffa calyces. Pharm Biol. 2016;54(12):3172-81

71. Lee W-C, Wang C-J, Chen Y-H, Hsu J-D, Cheng S-Y, Chen H-C, et al. Polyphenol extracts from Hibiscus sabdariffa Linnaeus attenuate nephropathy in experimental type 1 diabetes. J. Agr. Food Chem. 2009;57(6):2206-10.

72. Wang S-C, Lee S-F, Wang C-J, Lee C-H, Lee W-C, Lee H-J. Aqueous extract from Hibiscus sabdariffa Linnaeus ameliorate diabetic nephropathy via regulating oxidative status and Akt/Bad/14-3-3y in an experimental animal model. Evid-Based Compl. Alt. Med. 2011;2011.

73. Mohagheghi A, Maghsoud S, Khashayar P, Ghazi-Khansari M. The Effect of Hibiscus Sabdariffa on Lipid Profile, Creatinine, and Serum Electrolytes: A Randomized Clinical Trial, ISRN Gastroenterology. Volume 2011, doi:10.5402/2011/9760192010.

74. Chou ST, Lo HY, Li CC, Cheng LC, Chou PC, Lee YC, et al. Exploring the effect and mechanism of Hibiscus sabdariffa on urinary tract infection and experimental renal inflammation. J Ethnopharmacol. 2016;194:617-25.

75. Ali BH, Cahlikova L, Opletal L, Karaca T, Manoj P, Ramkumar A, et al. Effect of aqueous extract and anthocyanins of calyces of Hibiscus sabdariffa (Malvaceae) in rats with adenine-induced chronic kidney disease. J. Pharm. Pharmacol. 2017;69(9):1219-29.

76. Gheller AC, Kerkhoff J, Vieira Junior GM, De Campos KE, Sugui MM. Antimutagenic Effect of Hibiscus sabdariffa L. Aqueous Extract on Rats Treated with Monosodium Glutamate. Sci. 2017;2017:9392532.

77. Tanzima Y, Lt, Sup, Gt, Lt, Sup, et al. Growth Inhibition and Apoptosis of Ehrlich Ascites Carcinoma Cells by Methanol Extract from the Calyx of Hibiscus Sabdariffa Linn. CAJMS. 2018;4(2):155-65.

78. Reanmongkol $W$, Itharat A. Antipyretic activity of the extracts of Hibiscus sabdariffa $L$ calyces in experimental animals. Song. J. Sci.Tech. 2007;29(1):29-38.

79. Ali MK, Ashraf A, Biswas NN, Karmakar UK, Afroz S. Antinociceptive, anti-inflammatory and antidiarrheal activities of ethanolic calyx extract of Hibiscus sabdariffa Linn. (Malvaceae) in mice. Zhong xi yi 
jie hexue bao=J. Chin. Integr. Med. 2011;9(6):626-31.

80. Baihagi R, Hamidy MY, Eka B. Efek Analgetik Ekstrak Etanol Kelopak Rosella (Hibiscus sabdariffa L) Pada Mencit Jantan (Mus musculus). Jurnal Ilmu Kedokteran. 2017.

81. Iyare EE, Adegoke OA. Postnatal weight gain and onset of puberty in rats exposed to aqueous extracts of Hibiscus sabdariffa in utero. Pak. J. Nutr. 2008;7(1):98-101.

82. Iyare EE, Nwagha UI. Postweaning consumption of aqueous extract of Hibiscus sabdariffa may predispose rats to obesity. Pak. J. Nutr. 2009;8(11):1760-5

83. Orororo OC, Asagba SO, Tonukari NJ, Okandeji OJ, Mbanugo JJ. Cadmium-Induced Testicular Damage in Wistar Rats: Protective Effects of Hibiscus sabdariffa L. Anthocyanins. Int. J. Biochem. Res. Rev. 2018:1-8.

84. Ekanem EE, Aniema I, Charles EO, Okorie Pamela, Uzoigwe Jide Ugwu Princewill, et al. Effect of consumption of Hibiscus sabdariffa and Azadirachta inidca prenatally and postnatally on milk creamatocrit and early growth of offspring. Afri. J. Trad. Complement. Altern. Med. 2018;15(3):31-7.

85. Olaleye MT. Cytotoxicity and antibacterial activity of methanolic extract of Hibiscus sabdariffa. J. Med. Plant Res. 2007;1(1):009-13.

86. Fullerton M, Khatiwada J, Johnson JU, Davies S, Williams LL. Determination of antimicrobial activity of sorrel (Hibiscus sabdariffa) on Escherichia coli 0157: H7 isolated from food, veterinary and clinical samples. J. Med. Food. 2011;14(9):950-6.

87. Garbi MI, M. S. Saleh, Ali M. Badri, Ibrahim T. Ibrahim, Mohammed SF. Antibacterial activity, phytochemical screening and cytotoxicity of Hibiscus sabdariffa (calyx). Adv. Med. Plant Res. 2016;4(4):116-21.

88. Obiefuna P, Owolabi O, Adegunloye B, Obiefuna I, Sofola O. The petal extract of Hibiscus sabdariffa produces relaxation of isolated rat aorta. Pharm. Biol. 1994;32(1):69-74.

89. Fouda AMM, Mohamad H, Daba Y, D. GM. Inhibitory effects of aqueous extracts of Hibiscus sabdariffa on contractility of the rat bladder and uterus. Can. J. Physiol. Pharmacol. 2007;85(10):1020-
31.

90. Salah AM, Gathumbi J, Vierling W. Inhibition of intestinal motility by methanol extracts of Hibiscus sabdariffa L. (Malvaceae) in rats. Phytother. Res. 2002;16(3):283-5

91. Ahmed M, Alexander Z, I.Graya, O.Igolib J, A.Ferroa V, M.Drummond R. Hibiscus acid from Hibiscus sabdariffa (Malvaceae) has a vasorelaxant effect on the rat aorta. Fitoterapia. 2019;134:5-13.

92. Falade O, Otemuyiwa I, Oladipo A, Oyedapo O, Akinpelu B, Adewusi $S$. The chemical composition and membrane stability activity of some herbs used in local therapy for anemia. J. Ethnopharmacol. $2005 ; 102(1): 15-22$.

93. Adigun M, Ogundipe O, Anetor J, Odetunde A. Dose-dependent changes in some haematological parameters during short-term administration of Hibiscus sabdariffa Calyx aqueous extract (Zobo) in Wistar albino rats. Afr. J. Med. Med. Sci. 2006;35(1):73-7.

94. Chukwu CNEA. Comparative Investigation of the Effects of Different Aqueous Preparations of Hibiscus sabdariffa (Zobo Drinks) on Haematological Parameters in

Normal Wistar Albino Rats. Int. Blood Res. Rev. 2018;8(4):1-7.

95. Beltrán-Debón R, Alonso-Villaverde C, Aragonès G, RodríguezMedina I, Rull A, Micol V, et al. The aqueous extract of Hibiscus sabdariffa calyces modulates the production of monocyte chemoattractant protein-1 in humans. Phytomedicine. 2010;17(3-4):186-91.

96. Fakeye TO, Pal A, Bawankule DU, Khanuja SPS. Immunomodulatory effect of extracts of Hibiscus sabdariffa L. (Family Malvaceae) in a mouse model. Phytother. Res. 2008;22(5):664-8.

97. Owulade M, Eghianruwa K, Daramola F. Effects of aqueous extracts of Hibiscus sabdariffa calyces and ocimun gratissimum leaves on interstinal transit in rats. Afr. J. Biomed. Res. 2004;7(1):31-3.

98. Asuquo E, Friyanda E, Ifeanyi E, Akaninyene A. Staining Effect of Methanolic Extract of Hibiscus Sabdariffa Calyx on Thin Peripheral Blood Smear. J. Dis. 2019;6(1):1-6. 